\title{
PEMBAGIAN ANTROPOLOGI HUKUM
}

\author{
Ivandika Rahmad \\ Email : ivandikarahmad09@gmail.com \\ No BP : 2010003600114 \\ Fakultas Hukum Universitas Ekasakti Padang
}

\section{A. PENDAhuluan}

Antropologi sebagai salah satu cabang ilmu sosial mempunyai bidang kajian sendiri yang dapat dibedakan dengan ilmu sosial lainnya, seperti sosiologi, ilmu ekonomi, ilmu politik, kriminologi dan lain-lainnya. Antropologi juga dapat dikelompokkan ke dalam cabang ilmu humaniora karena kajiannya yang terfokus kepada manusia dan kebudayaannya. Sebagaimana sudah dijelaskan bahwa, secara umum dapat dikatakan antropologi merupakan ilmu yang mempelajari manusia dari segi keragaman fisiknya, masyarakatnya, dan kebudayaannya. Seperti yang pernah diungkapkan Koentjaraningrat bahwa ruang lingkup dan dasar antropologi belum mencapai kemantapan dan bentuk umum yang seragam di semua pusat ilmiah di dunia. Menurutnya, cara terbaik untuk mencapai pengertian akan hal itu adalah dengan mempelajari ilmu-ilmu yang menjadi pangkal dari antropologi, dan bagaimana garis besar proses perkembangan yang mengintegrasikan ilmu-ilmu pangkal tadi, serta mempelajari bagaimana penerapannya di beberapa negara yang berbeda.

Dalam antropologi terdapat pembagian pembahasan terkait manusia (bermasyarakat) diantaranya perkembangan fisik. Dimana perkembangan fisik tertarik pada sisi fisik dari manusia. Termasuk didalamnya mempelajari gen-gen yang menentukan struktur dari tubuh manusia. Mereka melihat perkembangan mahluk manusia sejak manusia itu mulai ada di bumi sampai manusia yang ada sekarang ini. Beberapa ahli Antropologi Fisik menjadi terkenal dengan penemuan-penemuan fosil yang membantu memberikan keterangan mengenai perkembangan manusia. Ahli Antropologi Fisik yang lain menjadi terkenal karena keahlian forensiknya; mereka membantu dengan menyampaikan pendapat mereka pada sidang - sidang pengadilan dan membantu pihak berwenang dalam penyelidikan kasus-kasus pembunuhan.

Sedangkan ruang lingkup manusia khusus budaya (bermasyarakat) lebih mengarah tingkah laku manusia. Dimana dalam antropologi lebih sering disebut Antropologi Budaya berhubungan dengan apa yang sering disebut dengan Etnologi. Ilmu ini mempelajari tingkah-laku manusia, baik itu tingkah-laku individu atau tingkah laku kelompok. Tingkah-laku yang dipelajari disini bukan hanya kegiatan yang bisa diamati dengan mata saja, tetapi juga apa yang ada dalam pikiran mereka. Pada manusia, tingkahlaku ini tergantung pada proses pembelajaran. Apa yang mereka lakukan adalah hasil dari proses belajar yang dilakukan oleh manusia sepanjang hidupnya disadari atau tidak. Mereka mempelajari bagaimana bertingkah-laku ini dengan cara mencontoh atau belajar 
dari generasi diatasnya dan juga dari lingkungan alam dan social yang ada disekelilingnya. Inilah yang oleh para ahli Antropologi disebut dengan kebudayaan. Kebudayaan dari kelompok-kelompok manusia, baik itu kelompok kecil maupun kelompok yang sangat besar inilah yang menjadi objek spesial dari penelitian-penelitian Antropologi Sosial Budaya. Dalam perkembangannya Antropologi Sosial-Budaya ini memecah lagi kedalam bentuk-bentuk spesialisasi atau pengkhususan disesuaikan dengan bidang kajian yang dipelajari atau diteliti.

Itulah sebabnya penelitian antropologis terhadap hukum sebagai salah satu aspek budaya dibedakan menjadi dua kelompok tujuan, yaitu: penelitian untuk kepentingan pengembangan Antropologi, dan penelitian untuk pengembangan Ilmu Hukum. Antropologi Hukum menekankan pada penelitian untuk pengembangan Ilmu Hukum (J.B.Daliyo cs : 1992 : 140).

\section{B. PEMbahasan}

Antropologi adalah salah satu cabang dalam ilmu sosial yang membahas budaya masyarakat suatu etnis. Antropologi sendirk timbul karena adanya ketertarikan dari orang Eropa yang melihat budaya, ciri-ciri fisik dan adat istiadat yang berbeda. Kata antropologi sendiri sebenarnya berasal dari bahasa Yunani "anthropos" serta "logos". Anthropos sendiri berarti manusia, sedangkan logos berarti ilmu. Sehingga antropologi bisa didefinisikan sebagai suatu ilmu yan mempelajari manusia menurut keanekaragaman fisik, dan juga kebudayaannya.

Sehingga pembagian obyek kajian antropologi merupakan manusia, kebudayaan dan juga perilakunya. Ini yang membuat obyek antropologi bersangkutan dengan semua manusia kapanpun dan dimanapun. Tujuan antropologi sendiri yaiti buat membangun masyarakat dengan cara mempelajari perilakunya. Perilaku dari beberapa faktor perubahan sosial bagaimana manusia bisa bermasyarakat dalam suku bangsa dan budaya manusia. Antropologi sendriri sebenarnya ilmu yang memadukan secara integratif serta bertujuan biologi serta sosio-budaya di kehidupan sehari-hari.

\section{Teori Antropologi dan Evolusionisme Deterministik}

Antropologi semakin ramai diperbincangkan karena adanya teori-teori yang bermunculan serta berkembang. Berikut teori antropologi yg berkembang di masyarakat. Teori Evolusionisme Deterministik bisa dikatakan merupakan bagian dari teori tertua diantara teori antropologi lainnya. Teori ini dikemvangkan oleh Lewis Henry Morgan serta Edward Burnet Tylor. Teori ini berhasil memunculkan adanya hukum universal, dimana hukum ini yang mengendalikan perkembangan keseluruhan kebudayaan manusia. Teori ini yang mendasari setiap kebudayaan serta mengalami fase-fase dan juga evolusi. 
Lewis Henry Morgan sendiri menggambarkan proses evolusi yang terjadi pada masyarakat serta kebudayaan kedalam delapan tahap evolusi universal. Gagasan ini dituangkan kedalam karyanya yang berjudul Ancient Society. Delapan tahapan ini terdiri atas zaman liar, zaman liar madya, zaman liar muda, zaman barbar tua, zaman barbar madya, zaman barbar muda, zaman peradaban purba serta zaman peradaban masa kini.

\section{Pembagian Jenis - jenis Antropologi}

Antropologi juga dibagi menjadi beberapa macam secara khusus adalah antropologi fisik serta antropologi budaya. Cabang antropologi ada beberapa macam-macam antropologi ini pun masih dibagi kedalam beberapa sub bidang, seperti berikut:

\section{Antropologi Fisik}

Antropologi fisik bagi Haviland yang mempelajari manusia menjadi obyek organisme biologis. Antropologi fisik lebih membahas pada manusia yang didasarkan pada evolusi serta menyelidiki manusia dengan berbagai variasi biologis kedalam berbagai macam atau spesies. Analisis antropologi fisik sendiri didapatkan dari fosil setta pengamatan kepada primata yang hidup pada jaman dahulu.

Para ahli antropologi fisik sendiri sebenarnya berusaha utnuk mencari tahu mengenai nenek moyang manusia. Buat mengetahui kapan, bagaimana, serta mengapa manusia berevolusi menjadi mahluk seperti saat ini.

Antropologi fisik juga dibagi menjadi beberapa sub bagian seperti berikut:

\section{a. Paleontologi}

Paleontologi merupakan kata yang berasal dari bahasa Yunani, paleon, ontos serta logos. Gabungan kata inilah yang kemudian diartikan menjadi ilmu yang mempelajari tentang kehidupan pada masa lalu. Paleontologi sendiri adalah keilmuan yang mempelajari asal usul dan juga perkembangan manusia biologis.

\section{b. Somatologi}

Somatologi merupakan salah satu bagian dari antropologi fisik yang membahas mengenai jenis ras manusia berdasarkan ciri-ciri fisik. Ciri fisik manusia seperti fenotip dan genotip akan dipelajari dalam ilmu somatologi. Somatologi juga membahas lebih lanjut mengenai sejarah terjadinya keanekaan warna manusia berdasarkan ciri-ciri tubuhnya. 


\section{Antropologi Budaya}

Burke jika antropologi budaya merupaman ilmu yang berfokus pada kebudayaan manusia. Dan juga berfokus cara hidup manusia dalam bermasyarakat. Antropologi budaya adalah salah satu studi tentang praktek sosial, bentuk ekspresif serta pemakaian bahasa. Antropologi budaya juga mempunyai tiga sub bidang sebagai berikut:

\section{a. Prehistori}

Prehistori yang menjadi salah satu bagian macam-macam kelompok sosial merupakan dari bidang antropologi budaya. Dimana berfokus serta mempelajari sejarah perkembangan, penyebaran serta tentang keragaman kebudayaan manusia sebelum mengetahui tulisan.

\section{b. Etnolinguistik}

Etnolinguistik nerupakan ilmu yang berfokus pada mengenai sejarah asal-usul, perkembangan serta penyebaran beragam bahasa yang dipakai oleh manusia.

\section{c. Etnologi}

Entologi merupakan bidang yang mempelajari ilmu kebudayaan didalam kehidupan bermasyarakat. Dari banyaknya suku bangsa yang berada diberbagai belahan dunia. Etnologi sendiri dibagi menjadi dua kajian yaitu antropologi diakronik serta antropologi sinkronik. Antropologi diakronik berfokus pada seperangkat pola budaya pada suku bangsa yang menyebar di berbagai belahan dunia. Berbeda dengan antropologi sinkronik yang mempelajari tingkah laku sosial didalam suatu lembaga. Seperti mengenai keluarga, kultur kebudayaan, tata hukum, sistem kekerabatan, serta organisasi politik.

\section{Antropologi Psikologi}

Antropologi psikologi merupakan bidang mengenai hubungan yang terjadi diantara individu dan nilai kebiasaan sosial. Yang berasal dari sistem pada sebuah budaya yang ada. Ruang lingkup dalam macam-macam kebutuhan manusia untuk antropologi psikologi sangatlah luas serta memakai berbagai macam pendekatan buat masalah yang muncul pada saat berinteraksi diantaranya adalah nilai, pemikiran serta kebiasaan sosial. Kajian berfokus antropologi psikologi merupakan kedekatan individu dalam bermasyarakat yang berhubungan dengan psikologi. Bisa dibilang jika kajian ini sangatlah besar kaitannya terhadap cabang cabang psikologi misalkan seperti psikologi organisasi. 


\section{Antropologi Spesialisasi}

Sama seperti beberapa antropologi, antropologi spesialisasi pun dibagi atas 3 sub bidang sebagai berikut :

\section{a. Antropologi Kesehatan}

Antropologi kesehatan yaitu keilmuan mengenai pengaruh terhadap unsur-unsur dalam budaya. Yang terjadi terhadap penghayatan masyarakat tentang penyakit serta kesehatan.

\section{b. Antropologi Ekonomi}

Antropologi Ekonomi yaitu bidang tentang antropologi yang mempelajari mengenai gejala ekonomi didalam kehidupan bermasyarakat. Tentunya dengan mengamati gaya hidup manusia serta sistem mengenai pencarian makanan yang subtantif.

\section{c. Antropologi Perkotaan}

Antropologi Perkotaan yaitu kajian mengenai pendekatan antropologi buat membahas tentang masalah perkotaan. Masalah perkotaan seringkali timbul serta berkembang menjadi ciri khas dari kota tersebut.

\section{d. Antropologi Kependudukan}

Antropologi Kependudukan merupakan kajian yang mempelajari bagaimana cara mengatasi masalah kependudukan. Beberapa masalah yang menghambat berjalannya program kependudukan seperti latar belakang serta kondisi sosial dalam budaya masyarakat.

\section{e. Antropologi Pendidikan}

Antropologi Pendidikan merupakan kajian yang bermanfaat buat mengasah kemampuan kognitif, psikomotorik serta afektiv didalam menganalisa, mensintesa, serta mengevaluasi tentang topik di sekitar antropologi.

\section{f. Antropologi Hukum}

Antropologi Hukum merupakan kajian yang berkaitan dengan norma sosial seperti halnya hukum. Jika terjadi sebuah pelanggaran maupun tindakan yang bertentangan terhadap norma sosial ini akan membuat pelanggar diberikan sanksi. 


\section{g. Antropologi Sosial}

Merupakan studi tentang ilmu antropologi guna mempelajari kebudayaan masyarakat pada suatu etnis. Ilmu ini juga mempelajari mengenai manusia dari sisi keberagamannya serta fisik seperti perilaku, tradisi, dan juga nilai - nilai budaya. Sehingga bisa dikatakan jika pengertian antropologi sosial merupakan kajian mengenai apa saja peristiwa didalam kehidupan manusia.

\section{h. Antropologi Forensik}

Antropologi forensik adalah kajian dari antropologi terapan dengan menggabungkan ilmu antropologi fisik atau biologi dengan ilmu Osteologi serta Ondotologi. Kedua ilmu inilah yang kemudian mempelajari mengenai kondisi tulang serta gigi. Antropologi forensik juga seringkali berkaitan dengan penggunaan osteologi serta odontologi untuk mengidentifikasi mayat.

\section{i. Antropologi Pembangunan}

Antropologi pembangunan merupakan kajian bagian dari kebudayaan. Pembangunan sendiri biasanya menandai eksistensi beberapa pola tingkah laku manusia. Sedangkan proses interaksi sosial dalam kebudayaan merupaka sebuah pedoman untuk mendasari manusia saat bertindak. Sehingga berdasarkan prespektif antropologi pembangunan seringkali dinilai mempungai tujuan buat membangun masyarakat dan juga peradaban manusia

\section{j. Antropologi Terapan}

Antropologi Terapan adalah kajian mengenai tempat keterampilan, pengetahuan serta sudut pandang terhadap ilmu antropologi. Antropologi Terapan seringkali dipakai buat mencari solusi terhadap masalah-masalah praktis tentang kemanusiaan. Dan juga menfasilitasi mengenai pembangunan manusia. Antropologi Terapan sering juga berkaitan terhadap masalah nyata serta berbagai kebutuhan didalam kelompok sosial pada masa kini. Misalkan seperti mengenai pengangguran, lalu konflik kelompok etnis, bencana alam, ethnic cleancing serta sebagainya. Antropologi terapan seringkali diketahui, dipelajari serta diaplikasikan buat menyesuaikan situasi kajian

\section{Pembagian Pendekatan Antripologi Hukum}

\section{Pendekatan Holistic}

Pendekatan Holistic merupakan pendekatan manusia sebagai makhluk ekonomi yang memandang kebudayaan dengan utuh atau holistik. Kebudayaan ini di pandang menjadi suatu yang holistik, karena setiap unsur padanya bisa dipahami secara 
terpisah. Para ahli antropologi bahkan mengumpulkan seluruh aspek seperti sejarah, ekonomi, geografi, teknologi dan juga bahasa guna memperoleh generalisasi terhadap kebudayaan yang kompleks.

\section{Pendekatan Komparatif}

Pendekatan komparatif merupakan sebuah pendekatan unik didalam antropologi. Pendekatan ini dipakai buat memahami suatu kebudayaan masyarakat yang masih belum mengenal baca-tulis atau pra-aksara. Para ahli antropologi sangat meyakini bahwa setiap teori perlu diuji sebanyak mungkin pada populasi serta kebudayaan sebelum bida diverifikasi. Ahli antropologi juga merasa jika lebih mudah buat mempelajari kebudayaan pada masyarakat kecil. Dimana relatif sama atau homogen dibandingkan masyarakat modern yang jauh lebih kompleks.

\section{Pendekatan Historic}

Pendekatan ini lebih berfokus pada asal-usul mengenai unsur kebudayaan. Pada awalnya para ahli antropologi sangat tertarik terhadap asal-usul unsur kebudayaan yang kemudian berubah tertarik terhadap unsur kebudayaan khusus serta unik.

Kajian Antropologi, menurut Stanley Wahburn, bidang kajian antropologi dibagi kedalam beberapa bagian sebagai berikut:

\section{Antropologi Sosial Budaya}

Antropologi budaya merupakan kajian yang mempelajari kebudayaan keseluruhan seperti akulturasi, perubahan budaya serta difusi kebudayaan. Konsep kunci didalam pengertian antropologi sosial merupakan struktur sosial serta bukanlah kebudayaan. Antropologi budaya lebih berfokus kepada pencarian sejarah yang didasari unsur-unsur kebudayaan. Sedangkan pengertian antropologi sosial lebih berfokus kepada pencarian hukum serta megeneralisasi lembaga-lembaga sosial.

\section{Antropologi Etnografi, Etnologi dan Linguistik}

Etnografi lebih mendeskripsikan secara lengkap mengenai kebudayaan yang masih ada hingga sekarang. Etnologi akan membandingkan serta menjelaskan kesamaan dan juga perbedaan diantara sistem kebudayaan. Linguistik lebih berfokus kepada cara mendeskripsikan serta menganalisis bahasa yang digunakan pada berbagai kebudayaan.

\section{Antropologi Prahistori}

Antropologi Prahistori lebih berfokus pada cara merekonstruksi sejarah masyarakat. Tentunya dengan cara menggali artefak serta unsur-unsur kebudayaan lain yang dimiliki. 
Itulah beberapa ulasan dari pengertian tentang antropologi sosial yang bisa anda ketahui bagaimana pengenalan teori dan macam-macamnya.

\section{PENUTUP}

Antropologi Hukum merupakan kajian yang berkaitan dengan norma sosial seperti halnya hukum. Jika terjadi sebuah pelanggaran maupun tindakan yang bertentangan terhadap norma sosial ini akan membuat pelanggar diberikan sanksi. Pembagian obyek kajian antropologi meliputi manusia, kebudayaan dan juga perilakunya. Ini yang membuat obyek antropologi bersangkutan dengan semua manusia kapanpun dan dimanapun. Tujuan antropologi sendiri yaiti buat membangun masyarakat dengan cara mempelajari perilakunya. Perilaku dari beberapa faktor perubahan sosial bagaimana manusia bisa bermasyarakat dalam suku bangsa dan budaya manusia. Antropologi sendriri sebenarnya ilmu yang memadukan secara integratif serta bertujuan biologi serta sosio-budaya di kehidupan sehari-hari.

Teori yang terkait dengan pembahasan ini Teori yang dikemvangkan oleh Lewis Henry Morgan serta Edward Burnet Tylor. Teori ini berhasil memunculkan adanya hukum universal, dimana hukum ini yang mengendalikan perkembangan keseluruhan kebudayaan manusia. Teori ini yang mendasari setiap kebudayaan serta mengalami fase-fase dan juga evolusi. Pembagian antropologi hukum ialah antropologi fisik, antropologi buda, ya, antropologi phisikologi, antropologi spesialisasi, antropologi pendidikan , antropologi sosial, antropologi kependudukan, dan antropologiforensik.

Studi ini merupakan studi tentang ilmu antropologi guna mempelajari kebudayaan masyarakat pada suatu etnis. Ilmu ini juga mempelajari mengenai manusia dari sisi keberagamannya serta fisik seperti perilaku, tradisi, dan juga nilai - nilai budaya. Sehingga bisa dikatakan jika pengertian antropologi sosial merupakan kajian mengenai apa saja peristiwa didalam kehidupan manusia.

\section{DAFTAR PUSTAKA}

Gokma Toni Parlindungan S, Asas Nebis In Idem Dalam Putusan Hakim Dalam Perkara Poligami Di Pengadilan Negeri Pasaman Sebagai Ceriminan Ius Constitutum, Volume 2, Nomor 1, 2020.

Gokma Toni Parlindungan S, Pengisian Jabatan Perangkat Nagari Pemekaran Di Pasaman Barat Dalam Rangka Pelaksanaan Otonomi Daerah, Ensiklopedia Of Journal, Vol 1 No 2 Edisi 2 Januari 2019,

Harniwati, Peralihan Hak Ulayat Menurut Undang-Undang Nomor 18 Tahun 2004, Volume 1, Nomor 3, 2019. 
Jasmir, Pengembalian Status Hukum Tanah Ulayat Atas Hak Guna Usaha, Soumatera Law Review, Volume 1, Nomor 1, 2018.

Jumrawarsi Jumrawarsi, Neviyarni Suhaili, Peran Seorang Guru Dalam Menciptakan Lingkungan Belajar Yang Kondusif, Ensikopedia Education Review, Vol 2, No 3 (2020): Volume 2 No.3 Desember 2020

Mia Siratni, Proses Perkawinan Menurut Hukum Adatdi Kepulauan Mentawai Di Sebelum Dan Sesudah Berlakunya Undang-Undang Nomor 1 Tahun 1974 Tentang Perkawinan, Ensiklopedia Of Journal, Vol 1 No 2 Edisi 2 Januari 2019,

Remincel, Dimensi Hukum Pelanggaran Kecelakaan Lalu Dan Angkutan Jalan Lintas Di Indonesia, Ensiklopedia Social Review, Volume 1, Nomor 2, 2019.

R Amin, B Nurdin, Konflik Perwakafan Tanah Muhammadiyah di Nagari Singkarak Kabupaten Solok Indonesia 2015-2019, Soumatera Law Review, Volume 3, Nomor 1, 2020. 